\title{
SHOULD PAID WORKFORCE PARTICIPATION BY OLDER PEOPLE BE ENCOURAGED? EVALUATING THE PROS AND CONS
}

\author{
Judith A. Davey \\ Senior Associate, \\ Institute for Governance and Policy Studies, \\ Victoria University of Wellington
}

\begin{abstract}
The policies of many developed countries now aim to encourage older people to remain longer in the paid workforce. What are the pros and cons of this position? Longer lives and better health in later life provide opportunities for prolonging workforce participation. There is considerable evidence that having meaningful and appropriate work is beneficial to the physical, psychological and financial wellbeing of older people. Demographic trends suggest that labour and skills shortages will become more pressing in the future as younger people entering the workforce do not balance the numbers retiring. Firms which understand the implications of ageing will be better placed to address its challenges. Older workers represent a valuable and often untapped source of increased productivity. But how can we ensure that their working conditions are appropriate rather than precarious? There are social and economic benefits from having an economically active older population. It will contribute to economic growth and the maintenance of living standards and also, through taxation, help to meet the costs of an ageing population. But what about the impact on the employment prospects of young workers and on voluntary work?
\end{abstract}

\section{The emergence of workforce ageing as a serious issue}

Up to around the year 2000, labour force participation trends in New Zealand, as in most OECD countries, could be summarised as women moving in and men moving out. Women's participation rates grew rapidly at all ages, but in the age groups 44 and over there were fewer men in paid work in 2001 than in 1961 (apart from a rise in participation for men aged 60-64 between to 1996 and 2001 as the age of eligibility for New Zealand Superannuation rose).

At that time early retirement was a key policy objective in many developed countries and was encouraged by pension policy settings and access to disability benefits. At that time, governments, employers, and unions alike thought of early retirement as a "peaceful solution to the economic problems of mass unemployment and industrial restructuring" (Ebbinghaus 2006). There has now been a complete turnaround in labour force policies as the challenges of population ageing have become recognised, especially the attendant costs of retirement income support, health and care provision. 
In November 2000 the Turin Charter -Towards active ageing- was adopted by the Conference of Labour Ministers of G-8 countries and endorsed by the G-8 Summit in 2001 (Taqi 2002). This advocated extending working lives on the basis that older people are an asset to society, entitled to active, independent and fulfilling lives (especially given extended longevity), and that this would contribute to economic growth, prosperity and social cohesion. OECD reports presented similar arguments, emphasising the fiscal costs of population ageing (OECD 2000; OECD 2006). Concern about the effects of labour force ageing was therefore a mixture of economic and social concerns.

In New Zealand, positive encouragement to extend working lives was also expressed around 2000, with the EEO Trust's Benchmark your workplace progress on age (EEO Trust 1999). This pointed out coming labour shortages and called for flexible work environments and phased retirement. The demographic drivers were illustrated in Treasury projections (Stephenson and Scobie 2002), which indicated that, due to population ageing and declining birth rates, labour force growth would slow and become negative by the 2020s, as large numbers of baby boomers exited the workforce and smaller cohorts followed them through the population.

There is a now widespread commitment to the belief that initiatives to maximise the potential of older workers and enhance their workforce capabilities will have economic and social advantages. Governments in many countries, especially the OECD and the European Union, are developing policies to increase labour force participation by older workers and discourage early retirement (Burniaux et al 2004; Watson Wyatt Worldwide 2004; OECD 2006).

This paper examines the benefits and disbenefits of this position for individuals, the economy, society and business. It draws on the findings of the paid employment objective of Making Active Ageing a Reality, a research project undertaken through the University of Waikato, funded by the Ministry of Business, Innovation and Employment. This research incorporated a review of relevant New Zealand and overseas academic, policy-related and business literature as well as investigative interviews carried out in mid-2013 in Auckland, Hamilton, Wellington and Christchurch. Working through the New Zealand Institute of Management and other contacts, 33 employers were interviewed, from a range of industries with workforces from under ten to several thousand. In addition, 26 key informants, from professional, commercial, trade union and public sector organisations involved in labour market issues and policies contributed their views on workforce ageing and policy responses.

\section{Benefits for individuals}

Longer lives and better health in later life provide an opportunity for prolonging participation in paid work. There is considerable evidence that meaningful and appropriate work is beneficial to the wellbeing of older people (Davey and Davies 2006). Ford and Orel (2005) point out that remaining in or re-entering the workforce has a positive psychological impact for older people; the habits of work routine are beneficial to a sense of wellbeing and accomplishment; work provides camaraderie and is linked to self-worth as opposed to retirement, which may be viewed as a non-role. Hinterlong et al.'s (2007) findings suggest that "productive engagement" can lead to improved health and functioning for older people. The British Department of Work and Pensions (DWP) research also showed that continuing to work in later life was associated with higher levels of self-reported health (Humphreys et al 2003). In the Ministry of Social 
Development report, The Business of Ageing (MSD 2011), working beyond the age of 65 is associated with higher satisfaction in retirement.

Participation in paid work will increase the incomes of older people, improving their material wellbeing in later life and helping to fulfil aspirations for higher standards of living (Johnson 2009). A strong imperative for remaining in the workforce is economic necessity (Jaworski 2005; McNair et al 2004; Munnell, Sass and Aubry 2006). For some, this is to recoup losses of savings in the global financial crisis. Working longer also reduces the period in retirement, shortening the time over which savings have to be spread. Johnson (2009) quotes USA data suggesting that older people could increase their retirement incomes by $9 \%$ by working one more year.

\section{Disbenefits for individuals}

At what age do the above benefits cease and how much work is too much? Many employees do not welcome the idea of work in later life. A "work till you drop" approach could lead to higher health costs, especially for workers in more stressful or physically demanding occupations (NZIER 2013a). Retirement is now seen as a legitimate phase of life, earned by a lifetime of paid work (Davey and Davies 2006). Employees and their unions have fought for the right to retire on a decent pension (Phillipson 1998). If this is not available as something to look forward to, the morale of the workforce could be affected.

Results presented by Cameron and Roskruge (2014) demonstrate an association between labour force status and life satisfaction for older New Zealanders. According to GSS data, those working full-time have lower life satisfaction than those not working, while those who are working parttime have slightly lower life satisfaction than those not working. This suggests that helping some older people to avoid the necessity of full-time work could potentially improve their wellbeing.

Older workers may feel they have very little control over how they do their jobs and limited opportunities for training, career guidance and promotion, leading to low job satisfaction (McNair et al. 2004). This, plus the stress of constant change, can lead to a deterioration of both physical and psychological health, at a time of life when age-related health problems may be beginning to affect some people. Hannif (2006) provides an example of this in the context of a New Zealand call centre. This has led to the suggestion that a substantial number of older workers are in precarious work, that is unstable, risky, low paid and unpredictable, often casualised, contingent, or part-time with no guarantee of tenure (Sargeant and Frazer 2009; Standing 2011).

Despite efforts by governments and others, ageism is still rife in the workplace and older workers often experience discrimination which pervades the entire employment relationship and can take a variety of forms. It occurs in relation to promotion, job allocation, salary differentials, access to training and staff benefits (e.g. age cut-off ages for life assurance cover and long service leave). General attitudes, as well as inter-staff action such as bullying and exclusion from social activities, can also disadvantage older workers (OGC Consulting 2013). Age discrimination is noted particularly in recruitment. Recruitment agents have been shown to apply age biases in deciding who to put forward for jobs. Bennington and Wein (2003) talked about "collusion" between recruitment agencies, human resources staff and managers in Australia, allowing discrimination to continue. Older workers may face particular difficulties when they seek to re-enter the workforce after redundancy or an absence for other reasons, 
including eldercare. As Leeson (2006, p.12) said: "Liberal democracies have been much slower in acknowledging the unfairness of age discrimination than they have been to squaring up to discrimination on grounds of race or sex. Unfavourable treatment of the young and the old has been persistently justified by appeal to its social utility."

Legislation to ban age discrimination has been enacted in many countries including the USA, Australia, Canada, New Zealand, Finland, Germany, Netherlands, Japan and through the European Union (Taylor 2002). In New Zealand, the Human Rights Act (HRA) came into effect in February 1999. But legislation has had limited success because of the difficulty of identifying age discrimination, because much of it is not overt, and discriminatory practices are deep seated in business culture. Measures against age discrimination will require more than legislation, although legislation has its place as a sanction and as a signal to society that such behaviour is not to be tolerated. There is a role for government, but also for the business community itself and for wider society.

\section{Benefits to society and the economy}

Extending the economically active life of older people will contribute to economic growth (MSD 2011). If productivity growth does not compensate for the predicted slowdown in labour force growth then there will be adverse economic consequences and an impact on the overall standard of living. Labour will become more expensive than capital and this ultimately affects the structure of the economy. There will also be an effect on savings and investment as people retire later to fund longer life spans.

Taxes paid and greater independence among older people will make it easier to provide support for those who need it in later life and thereby help to offset the increased costs of an ageing population (Liebfritz 2003). A British report, Active Ageing: Live Longer and Prosper, refutes the view that older people are a source of economic problems. It provides evidence that the benefits of living longer will outweigh the additional health and social care costs of population ageing. "In future decades, greater participation by people in their 60s and 70s in formal and informal work, alongside additional decreases in the number of life years spent with major disabilities, could increase national productivity by up to $10 \%$ of GDP" (Gill and Taylor 2012).

The ageing population will also change the demand side of the economy. The Business of Ageing estimates the value of unpaid work and consumer spending by older people (MSD 2011). National Seniors Australia (2009) provides an Australian example. NZIER examined the possible impacts on areas of household expenditure and predicts a demand shift in favour of products that older people use and consume (NZIER $a$ and $b$ ).

Society will be worse off if older people are not given the opportunity to use their skills and experience. Older people can contribute to society as role models and mentors in workplaces and in the community, thus helping to break down ageism and negative stereotypes. This will also contribute to intergenerational solidarity. Biggs, Carstensen and Hogan (2012) express this in terms of releasing accrued social capital among the older population, recognising that the process of adaptation to an ageing population is significant source of social innovation and business opportunity.

\section{Dis-benefits to society and the economy}




\section{Impact on volunteering and caring}

Older people make an enormous contribution to their communities and the voluntary sector through unpaid work (Davey and Davies 2006), which may be threatened by increased participation in the paid workforce. Ginn and Fast (2006) point out that prolonging workforce participation reduces the opportunities to provide care and support to other generations and to share activities with family and friends. This is particularly relevant to women, who are expected to respond to the needs of others. Many people in their fifties and sixties are caring for older family members, thus reducing demands on the state for eldercare. Many grandparents take on childcare responsibilities so that their adult children can work and contribute to the household budget (Mooney, Statham and Simon 2002). These activities may impinge on working lives, productivity, career aspirations, incomes and ability to save for their own retirement and produce strong motives to leave the labour market.

Studies, both in the UK and New Zealand, illustrate the difficulties of juggling caring responsibilities with paid work, and how lack of flexibility in the workplace may lead to withdrawal by older workers (Phillips, Bernard and Chittenden 2002; Keeling and Davey 2008). Considerable attention has been focused on family-friendly policies with respect to child-rearing, but less attention given to workers in mid-life with eldercare responsibilities, ranging from social contact to personal care. This is a major challenge in an ageing population.

\section{The "lump of labour" argument}

There is an argument that older people should leave the paid labour force to make way for younger workers. This is a hardy perennial in the news media and general comment. A good example was an article by Simon Collins in the Herald (February 17, 2012) with the headline Over-65s crowd teens out of market. This claimed that "Old people have displaced more than 40,000 teenagers from jobs in the past five years as more choose to stay on in the workforce and employers shun youth for experience." The main evidence produced for this assertion was research by the Salvation Army's social policy unit, which found that the number of 15 to 19year-olds in paid work dropped by 42,600 in the previous five years, while the numbers still working beyond 65 jumped by 40,200 . The conclusion was that employers were holding on to experienced workers past the traditional retirement age, at the expense of taking on inexperienced young people.

This argument is linked to the "lump of labour" theory, which assumes that the amount of work available is fixed and static - it is a zero-sum game -and that the job market works on a one-in, one-out basis. But most economists now accept that this theory is a fallacy. The US National Bureau of Economic Research collated academic papers from different countries, investigating whether older workers substitute or crowd out younger workers. Not a shred of evidence was found. The Institute for Fiscal Studies in the UK agreed with this conclusion. (Banks et al 2010) Quoting these sources, an Economist editorial, under the headline Why the old should not make way for the young (The Economist 2012), presented data showing that labour force participation of the old is positively associated with employment of the young. The economists conclude that society cannot become more prosperous by paying an increasing number of its citizens to become dependent and unproductive. If all older people left the workforce, the loss of their spending power would damage the economy and increase unemployment among all age groups. 
The reasons for youth unemployment can therefore not be placed at the door of older workers. Other factors are operating, including economic conditions, policies on youth training and apprenticeships, the funding of tertiary education and youth wage rates. In the longer term, demographic drivers will come into play.

\section{Benefits to Business}

Skills shortages are impacting business in many OECD countries (Callanan and Greenhaus 2008; Van Dalen et al 2009. The New Zealand Institute of Economic Research (NZIER 2013b) also concluded that workforce ageing will make labour scarce, so firms will bid up wages to try to acquire the labour they need.

Almost all the employers interviewed in recent New Zealand research agreed that labour and skill shortages are likely to become more pressing in the near future and recruitment will become harder (Davey 2014). One employer commented: "It is getting harder to find the right person; as organisations get leaner people need wider skills to be effective - at any age. And job descriptions become wider."

Many of the employers interviewed had encouraged the retention of older workers as valued and productive employees with experience and special skills. Some had long-standing options for people who wanted to scale down, becoming relievers or being rehired for fractional appointments. There was general agreement that business can benefit from encouraging workforce participation among older people, capitalising on their wisdom, maturity, experience (life and work), loyalty, commitment and know-how. There was emphasis on the retention of institutional knowledge and intellectual property. Older workers provide continuity and can pass knowledge on through coaching and mentoring. There were comments on the complementarity of young and older workers and the value of older workers vis-a-vis an ageing customer and consumer base.

Firms which understand the implications of population ageing and react positively will be better placed to address its challenges. Llewellyn and Chaix-Viros (2008 p. 5) concluded that "the agerelated workforce changes that lie ahead are among the most significant changes to which companies will have to adapt." Successful adaptation will require investment in human capital and knowledge management in mixed-age workforces (Lissenburgh and Smeaton 2003).

\section{Disbenefits to business}

These may be more perceived than real, and often arise from employers' negative attitudes towards older workers, based on myths and stereotypes which can easily be disproved (Gray and McGregor 2003; Davey 2007; Alpass and Mortimer 2007). This differs from the generally positive attitudes expressed in the Active Ageing research. In 2013, OGC (2013) surveyed their New Zealand clients; $32 \%$ mentioned benefits of employing older people but $52 \%$ brought up negative issues, citing older workers' inflexibility, reduced physical ability, enthusiasm and energy and lack of current skills. When respondents were asked if they were planning to implement or increase their focus on workforce ageing strategies over the next decade only $29 \%$ said yes (50\% said no, 21\% don't know). In response to the question "Does your organisation currently have any specific planning strategies around ageing workforce participation/utilisation?" 61\% said no, 34\% don't know and only 5\% said yes. 
The Active Ageing respondents were asked:"Do you think that employers' attitudes towards older workers need to change?" The answers were mixed and recognised that there is considerable variation in attitudes: "some could do better, others do well." There was a feeling that attitudes are changing, responding to economic necessity (labour and skills shortages) and demographic trends, especially the challenge of the baby boomers' retirement and growing workforce participation rates among older people. Instead of older workers being seen as a "pain in the butt" employers are beginning to see them as valuable and productive.

Changing attitudes have also been observed in Europe, as the implications of workforce ageing become clearer (Harper, Khan, Saxena and Leeson 2006). Walker (2006) also saw some evidence of shifts in employers' attitudes towards older workers, based on a business case. But, he suggested, progress is slow and haphazard, as Western labour markets suffer from endemic ageism. There is an "urgent need for public policies to encourage and support change among the majority (of businesses)" (p. 81).

\section{Conclusion - The Pros have it}

On balance the benefits of encouraging older people to prolong their participation in the paid workforce appear to outweigh the "cons". The disbenefits which have been outlined are generally based on attitudes which are changing or can be addressed by public policy and changes in business practices. Concerns about lack of strength, energy or failing health among older workers call for job redesign, ergonomic solutions and preventive measures. Concerns about lack of skills call for appropriate education and training responses, reflecting the needs of older workers. Addressing concerns about ageism and precarious work will benefit the whole workforce and society as a whole.

Workforce ageing is part of population ageing as a whole and is a trend which cannot be stopped. Biggs (2014) calls for "cultural adaptation" to ageing throughout society and the economy and part of this must be the adaptation of the workplace. 


\section{References}

Alpass, F. and Mortimer, R. (2007). Ageing Workforces and Ageing Occupations: A Discussion Paper. Wellington: Department of Labour.

Banks, J., Blundell, R., Bozio, A. and Emmerson, C. (2010). Releasing jobs for the young? Early retirement and youth unemployment in the United Kingdom. IFS Working Papers, London: The Institute for Fiscal Studies.

Bennington, L. and Wein, R. (2003). Does the resume open the door to age discrimination for older workers? Australasian Journal of Ageing, 22.2, 70-75.

Biggs, S. (2014) Adapting to an Ageing Society: the need for cultural change. Policy Quarterly, Special Issue - Ageing Population, 10. 3, 12-16.

Biggs,S., Carstensen, L. and Hogan, P. (2012). Social Capital, Lifelong learning and social innovation. In Beard, J., Biggs, S., Bloom, D., Fried, L., Hogan, P., Kalache, A. and Olshansky, S. eds (2012). Population Ageing: Peril or Promise. Geneva: World Economic Forum.

Burniaux, J-M., Duval, R. and Jaumotte, F. (2004). Coping with ageing: a dynamic approach to quantify the impact of alternative policy options on future labour supply in OECD countries. OECD working paper 371. Paris: Organisation for Economic Cooperation and Development.

Callanan, G. and Greenhaus, J. (2008). The Baby Boom Generation and Career Management: a Call to Action. Advances in Developing Human Resources, 10.1. p.70-85.

Cameron, M. and Roskruge, M. (2014). Labour Force Participation and Well-being among Older New Zealanders. Policy Quarterly, Special Issue - Ageing Population, 10, 3, 35-41.

Davey, J. (2007). Maximising the Potential of Older Workers (revised edition). Wellington: New Zealand Institute for Research on Ageing.

Davey, J. (2014). Age discrimination in the workplace. Policy Quarterly, Special Issue - Ageing Population, 10, 3, 42-48.

Davey, J. and Davies, M. (2006). Work In Later Life - Opportunity or Threat? Social Policy Journal of New Zealand, 27, 20-37.

Ebbinghaus, B. (2006). Reforming early retirement in Europe, Japan and the USA. Oxford University Press: UK / USA.

EEO Trust (1999). Benchmark your workforce progress on age. Auckland: Equal Employment Opportunities Trust.

Ford, R. and Orel, N. (2005). Older Adult Learners in the Workforce. Journal of Career Development, 32.2, 139-152. 
Gill, J. and Taylor, D. (2012). Active Ageing: Live longer and prosper. London: University College London.

Ginn, J. and Fast, J. (2006). Employment and Social Integration in Midlife: Preferred and Actual Time Use across Welfare Regime Types. Research on Aging, 28.6, 669-690.

Hannif, Z. (2006). Stuck for choice? The work life experiences of mature-aged workers in a New Zealand call centre. Labour, Employment and Work in New Zealand Twelfth Conference, November 2006.

Hinterlong, J., Morrow-Howell, N. and Rozario P. (2007). Productive Engagement and Late Life Physical and Mental Health: Findings from a Nationally Representative Panel Study. Research on Aging, 29, 348-370.

Humphreys, A., Costigan, P., Pickering, K., Stratford, N. and Barnes, M. (2003). Factors affecting the labour market participation of older workers. Department for Work and Pensions Research Report 200, Norwich: H.M. Stationery Office.

Grey, L. and McGregor, J. (2003). Human Resource Development and Older Workers: Stereotypes in New Zealand. Asia Pacific Journal of Human Resources, 41.3. 338- 353.

Hudson (2004). The Hudson Report: New Zealand Ageing Population - Implications for Employers. Hudson Australia/New Zealand.

Harper, S., Khan, H., Saxena, A. and Leeson, G. (2006). Attitude and Practices of Employers towards Ageing Workers: Evidence from a Global Survey in the Future of Retirement. Ageing Horizons, 5, 31-41.

Jaworski, B. (2005). Aging Workers, Changing Value. Journal of Employee Assistance, $\mathbf{1}^{\text {st }}$ Quarter, p.22-23

Johnson, R. (2009).Employment Opportunities at Older Ages. Research on Aging, 31.1, 3-16.

Keeling, S. and Davey, J. (2008).Working carers in New Zealand: zones of care and contested boundaries. In Martin-Matthews, A. and Phillips, J. (Eds) Ageing and Caring at the intersection of Work and Home Life: Blurring the Boundaries. London: Psychology Press.

Leeson, G. (2006). The Employment Equality (Age) Regulations and Beyond. Ageing Horizons, 5, 12-19. Oxford Institute of Ageing.

Liebfritz, W. (2003). Retiring later makes sense. OECD Observer, 234, October 2002

http://www.oecdobserver.org/news/archivestory.php/aid/824/Retiring_later_makes_sense.ht $\mathrm{ml}(2 / 7 / 14)$

Lissenburgh, S. and Smeaton, D. (2003). Employment transitions of older workers: The role of flexible employment in maintaining labour market participation and promoting job quality, Joseph Rowntree Foundation, Bristol: The Policy Press. 
Llewellyn, J. and Chaix-Viros, C. (2008). The Business of Ageing: Older workers, older consumers; big implications for companies. London: Nomura International Plc.

McNair, S., Flynn, M., Owen, L., Humphreys, C. and Woodfield, S. (2004). Changing Work in Later Life: A Study of Job Transitions. Guildford: Centre for Research into the Older Workforce, University of Surrey.

Mooney, A., Slatham, J. and Simon, A. (2002). The Pivot Generation: Informal care and work after 50. Bristol: The Policy Press.

Munnell, A., Sass, S. and Aubry, J-P. (2006). Employer survey: 1 of 4 boomers won't retire because they can't. Work Opportunities for Older Americans, Series 6. Boston College: Centre for Retirement Research.

MSD (2011). The Business of Ageing: Realising the economic potential of older people in New Zealand: 2011-2051. Wellington: Ministry of Social Development.

National Seniors Australia (2009). Experience Works: The Mature Age Employment Challenge. National Seniors Australia Productive Ageing Centre. Canberra: Australian Government, Department of Health and Ageing.

NZIER (2013a). Golden years? The impacts of New Zealand's ageing on wages, interest rates, wealth and macro economy. NZIER working paper 2013/01, Wellington: New Zealand Institute of Economic Research.

NZIER (2013b). Hi ho silver lining? What firms need to think about as New Zealand ages. NZIER working paper 2013/02, Wellington: New Zealand Institute of Economic Research.

OECD (2000). Reforms for an Ageing Society. Paris: Organisation for Economic Cooperation and Development.

OECD (2006). Live Longer, Work Longer. Paris: Organisation for Economic Cooperation and Development.

OGC Consulting (2013). Coming of Age: The Impact of an Ageing Workforce on New Zealand Business. Wellington and Auckland: OGC Consulting.

Phillips, J., Bernard, M. and Chittenden, M. (2002). Juggling Work and Care: The Experiences of Working Carers of Older Adults. York: Joseph Rowntree Foundation.

Phillipson. C. (1998). Changing work and retirement: older workers, discrimination and the labour market. In Bernard, M. and Phillips, J. (eds) The social policy of old age: moving into the 21st century, London: Centre for Policy on Ageing.

Sargeant, M. and Frazer, A. (2009). Older workers as vulnerable workers in the new world of work. Sydney: 15th World Congress of the International Industrial Relations Association (IIRA).

Standing, G. ( 2011). The Precariat: The New Dangerous Class. London: Bloomsbury Academic. 
Stephenson, J. and Scobie, G. M. (2002). The Economics of Population Ageing, Wellington: The Treasury.

Taqi, A. (2002). Older people, work and equal opportunities. International Social Security Review, 55, 107-120.

Taylor, P. (2002). New policies for older workers. Joseph Rowntree Foundation, Transitions after 50 series. Bristol: The Policy Press.

The Economist (2012). Why the old should not make way for the young (February 11, 2012). http://www.economist.com/node/21547263 (21/5/13).

Van Dalen, H., Henkens, K. and Schippers, J. (2009). Dealing with older workers in Europe: a comparative survey of employers' attitudes and actions. Journal of European Social Policy, 19.1, 47-60.

Walker, A. (2006). Active Ageing in Employment: Its Meaning and Potential. Asian-Pacific Review, 13,1, p.78-92.

Watson Wyatt Worldwide (2004). Living Happily Ever After: the economic implications of aging societies. A report to the World Economic Forum, http://www.watsonwyatt.com/research/resrender. asp?id=0NL009andpage=1 (27/6/05) 